\title{
Article \\ Improved Durability of Wood Treated with Nano Metal Fluorides against Brown-Rot and White-Rot Fungi
}

\author{
Shirin M. Usmani ${ }^{1,2}$, Linn Voss ${ }^{3}$, Ina Stephan ${ }^{2}$, Thomas Hübert ${ }^{2}$ and Erhard Kemnitz ${ }^{1, * \mathbb{D}}$ \\ 1 Department of Chemistry, Humboldt-Universität zu Berlin, Brook-Taylor Str. 2, 12489 Berlin, Germany; \\ shirin.usmani@hu-berlin.de \\ 2 Bundesanstalt für Materialforschung und-prüfung (BAM), Unter den Eichen 87, 12205 Berlin, Germany; \\ ina.stephan@bam.de (I.S.); thomas.huebert@bam.de (T.H.) \\ 3 Bundesinstitut für Risikobewertung (BfR), Max-Dohrn-Straße 8-10, 10589 Berlin, Germany; \\ linn.voss@bfr.bund.de \\ * Correspondence: erhard.kemnitz@chemie.hu-berlin.de
}

check for updates

Citation: Usmani, S.M.; Voss, L.; Stephan, I.; Hübert, T.; Kemnitz, E. Improved Durability of Wood Treated with Nano Metal Fluorides against Brown-Rot and White-Rot

Fungi. Appl. Sci. 2022, 12, 1727. https://doi.org/10.3390/app12031727

Academic Editors: Réh Roman and Petar Antov

Received: 10 January 2022

Accepted: 1 February 2022

Published: 8 February 2022

Publisher's Note: MDPI stays neutral with regard to jurisdictional claims in published maps and institutional affiliations.

Copyright: (C) 2022 by the authors. Licensee MDPI, Basel, Switzerland. This article is an open access article distributed under the terms and conditions of the Creative Commons Attribution (CC BY) license (https:// creativecommons.org/licenses/by/ $4.0 /)$.

\begin{abstract}
Low-water soluble metal fluorides such as magnesium fluoride $\left(\mathrm{MgF}_{2}\right)$ and calcium fluoride $\left(\mathrm{CaF}_{2}\right)$ were evaluated for decay protection of wood. Initially, the biocidal efficacy of nano metal fluorides (NMFs) against wood destroying fungi was assessed with an in-vitro agar test. The results from the test showed that agar medium containing $\mathrm{MgF}_{2}$ and $\mathrm{CaF}_{2}$ was more efficient in preventing fungal decay than stand-alone $\mathrm{MgF}_{2}$ or $\mathrm{CaF}_{2}$. These metal fluorides, in their nanoscopic form synthesized using fluorolytic sol-gel synthesis, were introduced into the sapwood of Scots pine and beech wood and then subjected to accelerated ageing by leaching (EN 84). MAS ${ }^{19} \mathrm{~F} \mathrm{NMR}$ and $\mathrm{X}$-ray micro CT images showed that metal fluorides were present in treated wood, unleached and leached. Decay resistance of Scots pine and beech wood treated with NMFs was tested against wood destroying fungi Rhodonia placenta and Trametes versicolor in accordance with EN 113. Results revealed that mass losses were reduced to below $3 \%$ in wood treated with the combination of $\mathrm{MgF}_{2}$ and $\mathrm{CaF}_{2}$. It is concluded that NMFs provide full protection to wood even after it has been leached and can be used as wood preservatives in outdoor environments.
\end{abstract}

Keywords: fluoride; nanoparticles; fluorolytic sol-gel synthesis; brown-rot fungi; white-rot fungi; basidiomycetes; wood protection; biocidal efficacy

\section{Introduction}

Products made from wood such as those used in construction are known to be environmentally sustainable. In comparison to concrete and steel, wood-framed buildings have the lowest carbon footprint and can function as a carbon sink [1,2]. The energy required to construct a house using timber is lower than steel or concrete [3]. It is estimated that use of timber instead of steel or concrete for new building projects can function in storing 20 gigatons of carbon [1]. Choosing timber over other construction materials can play an important tool in climate change mitigation strategies, although it is vulnerable to degradation by organisms such as fungi. Therefore, protection of wood products from decay aimed at extending their service life is highly important.

Commercially, various preservative formulations and modification techniques are available to protect wood from wood-degrading organisms [4,5]. In modification methods, the hydrophobicity of wood is increased to reduce its moisture content that increases its resistance to wood-degrading organisms and termites [4]. Recent chemical modification methods have shown that the combination of polyethylene glycol (PEG) with silica sol impregnation improved the hydrophobicity of wood, though results on durability against wood-degrading fungi have not been reported [6]. Another study reported that titanium alkoxide modified wood had mass losses up to 5\% against Coniophora puteana, however the specimens were unleached [7]. 
Among preservative formulations, copper still remains the most extensively used active ingredient for wood protection, closely followed by boron $[8,9]$. To provide sufficient protection the active ingredient in preservative formulations needs to be uniformly distributed inside wood. One method to improve the distribution of preservative formulations in wood has focused on using active ingredients in their nanoscopic form. Developments in this area has led to micronized copper $(\mathrm{Cu})$ taking over $50 \%$ of the commercial $\mathrm{Cu}$ containing preservative market in North America [10]. In addition to copper, nanoparticles of active ingredients such as boron (B), silver $(\mathrm{Ag})$, titanium dioxide $\left(\mathrm{TiO}_{2}\right)$, and zinc $(\mathrm{Zn})$ have been assessed for their biocidal efficacy against wood-degrading fungi [11]. $\mathrm{Cu}$ and $\mathrm{Ag}$ nanoparticles in particleboard resulted in mass losses greater than $10 \%$ [12]. Similarly, nanoparticles of copper oxide $(\mathrm{CuO})$ and zinc oxide $(\mathrm{ZnO})$ dispersed in propylene glycol tested in rubberwood against white-rot and brown-rot fungi led to mass losses greater than 10\% [13]. Still, $\mathrm{ZnO}$ nanoparticles protected sapwood of Scots pine and beech wood specimens which had been artificially aged by leaching against white-rot fungi, Trametes versicolor [14]. Yet the same treatment in pine wood resulted in high mass losses against brown-rot fungi $C$. puteana [14]. Combination of $\mathrm{TiO}_{2}$ and $\mathrm{ZnO}$ were also evaluated in poplar wood which resulted in mass losses below $1 \%$ against T. versicolor [15]. Although these treated wood specimens were UV weathered, they did not undergo accelerated ageing through leaching. Another study reported that nano $\mathrm{ZnO}$ treatment alone did not protect against brown-rot fungus, Rhodonia placenta, but nano zinc borate reduced mass losses in wood to below 1\% [16]. However, results on nano zinc borate treated specimens that were leached and exposed to Rhodonia placenta were not reported. One nano-based treatment that showed resistance against $R$. placenta and C. puteana in spruce wood specimens that were leached was $\mathrm{TiO}_{2} /$ Cerium (Ce) [17]. Still, it is not known if $\mathrm{TiO}_{2} / \mathrm{Ce}$ would protect wood from white-rot fungi, T. versicolor. Thus, so far there is no single nano-based treatment reported that protects wood against decay caused by R. placenta and T. versicolor.

Fluorides had been also widely used in wood preservative formulations. Fluoridebased preservatives were reported to have efficacy against basidiomycetes with average threshold values of $1 \mathrm{~kg} / \mathrm{m}^{3}$ in wood [18]. However, use of fluoride in water-borne preservative formulations has steadily declined. One of the limitations of fluoride compounds such as sodium fluoride $(\mathrm{NaF})$ and sodium fluorosilicate $\left(\mathrm{Na}_{2} \mathrm{SiF}_{6}\right)$ is their solubility which makes them highly susceptible to leaching. Recent research on NaF treatment in wood with ground contact reported that more than $90 \%$ of fluoride was lost which resulted in more than $10 \%$ mass losses against termites, Reticulitermes flaviceps [19]. Also, the reported higher leachability of $\mathrm{NaF}$ was in agreement with results on NaF-treated particleboard [20]. Loss of fluoride from treated wood reduces the formulations protective capacity against fungal decay in outdoor applications where exposure to precipitation cannot be avoided. It is known that fluorides that are not fixed in wood with chromium compounds are highly leachable [18]. However, restrictions were introduced on the use of chromium by the European Commission that governs the use of biocides [21]. These regulations have limited the use of chromium and thereby resulted in the decline of fluoride-based preservatives.

An alternative to conventional metal fluorides used in preservative formulations would be low-water soluble metal fluorides such as $\mathrm{MgF}_{2}$ and $\mathrm{CaF}_{2}$. Their biocidal efficacy potential was reported in 1926 [22]. However, until recently no results were reported on durability of wood treated with these fluorides. A major limitation of treating wood with crystalline, low- water soluble fluorides is their size; they are too large to penetrate in wood cavities. This limitation was circumvented by accessing their nanoscopic form via fluorolytic sol-gel synthesis [23]. The nanoparticles of metal fluorides also known as nano metal fluorides (NMFs) were characterized by XRD and TEM which confirmed their composition and nano-size [23]. The resultant NMF treated wood was characterized by back-scattered electron images that showed aggregates of NMFs homogeneously distributed in the wood matrix. In addition, nano metal fluorides showed efficacy against brown-rot fungi, Coniophora puteana and termites, Coptotermes formosanus with mass losses below 3\% [24]. However, the NMF treatment did not provide sufficient protection from 
Rhodonia placenta [23]. The results presented here were obtained from optimized NMF formulations that fully protected treated wood against $R$. placenta. In addition, the efficacy of nano metal fluorides was tested against white-rot fungus, Trametes versicolor. Therefore, the following presents the durability of NMF treated wood against brown-rot fungus, R. placenta and white-rot fungus, T. versicolor.

\section{Materials and Methods}

\subsection{Sol-Synthesis}

The synthesis of $\mathrm{MgF}_{2}$ and $\mathrm{CaF}_{2}$ sols has been described previously using fluorolytic sol-gel method which involved fluorination of a suitable precursor with ethylene glycol as solvent [23]. The synthesis of the combination of $\mathrm{MgF}_{2}$ and $\mathrm{CaF}_{2}$ sol $(1.25 \mathrm{M})$ is as follows. In $530 \mathrm{~mL}$ ethylene glycol (Sigma Aldrich, Baden-Württemberg, Germany), $337.5 \mathrm{mmol}$ of calcium oxide (CaO, 96\% Sigma Aldrich, Baden-Württemberg, Germany) and 37.5 mmol calcium chloride $\left(\mathrm{CaCl}_{2}, 98 \%\right.$ Sigma Aldrich, Baden-Württemberg, Germany) was dissolved and then fluorinated with $750 \mathrm{mmol}$ of aqueous HF (39.24 M, Steinebach Chemie, Lüdenscheid, Germany). Then, $375 \mathrm{mmol}$ of $\mathrm{Mg}(\mathrm{OEt})_{2}(99.8 \%$, Evonik Industries, Essen, Germany) was added to this suspension and fluorinated with $750 \mathrm{mmol}$ of aqueous HF. The solution was stirred for two days to obtain a clear colloidal NMF sol. The hydrodynamic diameter of $\mathrm{MgF}_{2}$ and $\mathrm{CaF}_{2}$ in sols were less than $25 \mathrm{~nm}$ as determined by dynamic light scattering and reported previously [23].

\subsection{Characterization of Nanoparticles}

For STEM measurement, the combination of $\mathrm{MgF}_{2}$ and $\mathrm{CaF}_{2}$ sol was dispersed in ethanol and $10 \mu \mathrm{L}$ of it was transferred on a conventional carbon hole film with a thickness of $20 \mathrm{~nm}$ supported on a copper grid. After complete evaporation of the ethanol from the grid, the particles were studied on a JEOL TEM 2200 FS that was operated at an acceleration voltage of $200 \mathrm{kV}$.

\subsection{In-Vitro Agar Test}

An in-vitro agar test was done to evaluate the biocidal efficacy of NMFs against fungi which has been described previously [25]. The test was done on two fungal species: R. placenta (FPRL 280) and T. versicolor (CTB 863 A). Two concentrations of NMF; $0.05 \mathrm{M}$ and $0.4 \mathrm{M}$, in three formulations; $\mathrm{MgF}_{2}, \mathrm{CaF}_{2}, \mathrm{MgF}_{2}+\mathrm{CaF}_{2}$ were tested in triplicate. In a $20 \mathrm{~mL}$ medium of $5 \%$ malt extract and 3\% agar, NMF sols were added in different amounts to get the respective final concentration of $0.05 \mathrm{M}$ and $0.4 \mathrm{M}$ and then sterilized. After the medium solidified, an inoculum $(0.25 \mathrm{~cm})$ from a fungal culture was placed in each Petri dish. The Petri dishes were incubated at $20 \pm 2{ }^{\circ} \mathrm{C}$ and $65 \pm 5 \% \mathrm{RH}$. The measurements were done in triplicate. The anti-fungal efficacy was assessed by measuring the size of the fungal colony diameter in centimeters after 14 days.

\subsection{Wood Treatment, Leaching, and Fungal Test}

The NMF sols were diluted in ethanol to obtain the final concentration for impregnating into wood specimens. The durability of treated wood specimens against $R$. placenta and T. versicolor was assessed by fungal decay test performed in accordance with the European standard EN 113 [26]. Scots pine (Pinus sylvestris) sapwood and beech (Fagus sylvatica) specimens were used to test for efficacy against $R$. placenta and T. versicolor, respectively. The dimensions of the wood specimens were $15 \mathrm{~mm} \times 25 \mathrm{~mm} \times 50 \mathrm{~mm}$ (radial $\times$ tangential $\times$ longitudinal) Specimens were oven-dried at $103 \pm 2{ }^{\circ} \mathrm{C}$ for $18 \mathrm{~h}$ and then evacuated at $0.4 \pm 0.2 \mathrm{kPa}$ for $1 \mathrm{~h}$. After evacuation, the treatment solution was introduced into the vessel and the specimens were soaked in it for $2 \mathrm{~h}$ at ambient pressure and room temperature. Following soaking, the specimens were placed in a conditioning room $\left(20 \pm 2{ }^{\circ} \mathrm{C}\right.$ and $\left.65 \pm 5 \% \mathrm{RH}\right)$ for 4 weeks. After conditioning, the treated specimens were leached according to the accelerated ageing test set by the European standard EN 84 [27]. Specimens were submerged in 
deionized water and evacuated at $4 \mathrm{kPa}$ for $20 \mathrm{~min}$. The water was changed nine times, during a period of 14 days.

After leaching, the specimens were conditioned for 4 weeks and then autoclaved at $121^{\circ} \mathrm{C}$ for $30 \mathrm{~min}$. The wood specimens were tested against Rhodonia placenta (FPRL 280) and Trametes versicolor (CTB 863 A). Nano metal fluoride treated wood was tested against $R$. placenta and T. versicolor according to EN 113 (1996) over 16 weeks. The treated specimens were leached before the fungal test. Untreated wood specimens were used to show the virulence of the fungi during the test period, these are called virulence specimens. Four replicates of each treatment were tested in Kolle flasks. One NMF treated specimen and an untreated specimen were introduced into each Kolle flask and then exposed to the selected fungi growing on malt-agar medium for 16 weeks. Additionally, treated specimens were put only on malt-agar medium in a Kolle flask, to determine the mass loss not due to fungal decay at the end of the test, this is known as the correction value. The mass loss was calculated as the difference between the initial and final dry mass of the treated specimen at the end of the decay test.

\subsection{Characterization of Treated Wood}

X-ray micro-CT was performed on a Phoenix v|tome|x L 300/180. The specimen was scanned using an open type microfocus transmission X-ray tube at $60 \mathrm{kV}, 170 \mu \mathrm{A}, 3000$ projections, and $6000 \mathrm{~ms}$ exposure time per projection. Reconstructions were performed with the datos $\mid x$ reconstruction software package, a tomography reconstruction package for cone-beam from GE Sensing \& Inspection Technologies $\mathrm{GmbH}$ phoenix|x-ray, resulting in reconstructed data with a voxel size of $12 \mu \mathrm{m}$. The reconstructed volumes were analyzed using 3D Imaging software, CT Viewer, licensed by BAM.

Treated wood was grounded and analysed by solid-state MAS ${ }^{19} \mathrm{~F}$ NMR spectroscopy to confirm the chemical composition of metal fluorides. Solid-state MAS (magic angle spinning) NMR spectra were recorded on a Bruker AVANCE 400 spectrometer at room temperature. A $2.5 \mathrm{~mm}$ rotor was filled with grounded NMF treated wood and then ${ }^{19} \mathrm{~F}$ (Larmor frequency of $376.4 \mathrm{MHz}$ ) was measured using rotation frequency of $20 \mathrm{kHz}$. All

${ }^{19} \mathrm{~F}$ MAS spectra of wood specimens were recorded using a $\pi / 2$ pulse length of $4.4 \mu \mathrm{s}$, a spectrum width of $400 \mathrm{kHz}$, a recycle delay of $5 \mathrm{~s}$, and an accumulation number of 2048 .

\subsection{Cytotoxicity Assay}

\subsubsection{Cell Cultivation}

All cells were cultivated in DMEM High Glucose, 10\% fetal calf serum (FCS), and $100 \mathrm{U} / \mathrm{mL}$ penicillin $100 \mu \mathrm{g} / \mathrm{mL}$ streptomycin (GE Healthcare, Solingen, Germany). HepG2 cells were seeded into 96-well plates with a density of 20,000 cells per well and used for experiments $24 \mathrm{~h}$ after seeding. Caco- 2 cells were seeded with a density of 5000 cells per well and differentiated over 21 days. During this period, the medium was changed every $2-3$ days.

\subsubsection{Cytotoxicity Assays}

Cell viability was measured by the Cell Titer Blue assay (CTB; Promega, Madison, WI, USA) followed by the MTT assay. HepG2 cells were incubated in a volume of $100 \mu \mathrm{L}$ for $24 \mathrm{~h}$ in 96-well-plates. After the incubation time, $20 \mu \mathrm{L}$ CTB reagent (1:4 in PBS) were added. For Caco- 2 cells, $250 \mu \mathrm{L}$ of test substance were used and $40 \mu \mathrm{L}$ of undiluted CTB reagent was added. After CTB incubation of 30 to $60 \mathrm{~min}$, fluorescence was measured with a Tecan plate reader (Ex.- $560 \mathrm{~nm}$, Em.- $590 \mathrm{~nm}$ ). Subsequently, $10 \mu \mathrm{L}$ of $5 \mathrm{mg} / \mathrm{mL}$ 3-(4,5-Dimethylthiazol-2-yl)-2,5-diphenyltetrazolium bromide (MTT, Sigma Aldrich) in PBS was added for another hour. Afterwards, media were removed and $130 \mu \mathrm{L}$ desorption agent $(0.7 \% w / v$ SDS in isopropanol) was added. Plates were shaken for $30 \mathrm{~min}$ and absorption was measured with a plate reader $(570 \mathrm{~nm})$ while background absorption $(630 \mathrm{~nm})$ was subtracted. Results are given normalized to untreated controls, after subtraction of equally treated cell-free reference wells. Triton X-100 $(0.01 \%)$ was used as a positive control. 
Statistics were performed as one way ANOVA followed by Dunnett's test indicated by asterisks $\left({ }^{*} p<0.05 ;{ }^{* *} p<0.01 ;{ }^{* *} p<0.001\right)$.

\section{Results}

\subsection{Characterization of Nano Metal Fluorides}

The Figure 1a presents the high-angle annular dark field scanning transmission electron microscopy (HAADF-STEM) image of nanoparticles of $\mathrm{MgF}_{2}$ and $\mathrm{CaF}_{2}$ synthesized in one sol and the corresponding energy dispersive spectroscopy map (Figure 1b-d). From Figure 1a, it is seen that particle sizes are less than $20 \mathrm{~nm}$. The small size of these low-water soluble metal fluorides enables them to be distributed inside wood during treatment. Additionally, elemental mapping presented in Figure $1 \mathrm{~b}-\mathrm{d}$ confirmed that both $\mathrm{MgF}_{2}$ and $\mathrm{CaF}_{2}$ particles are present in the sol with the latter forming larger aggregates.
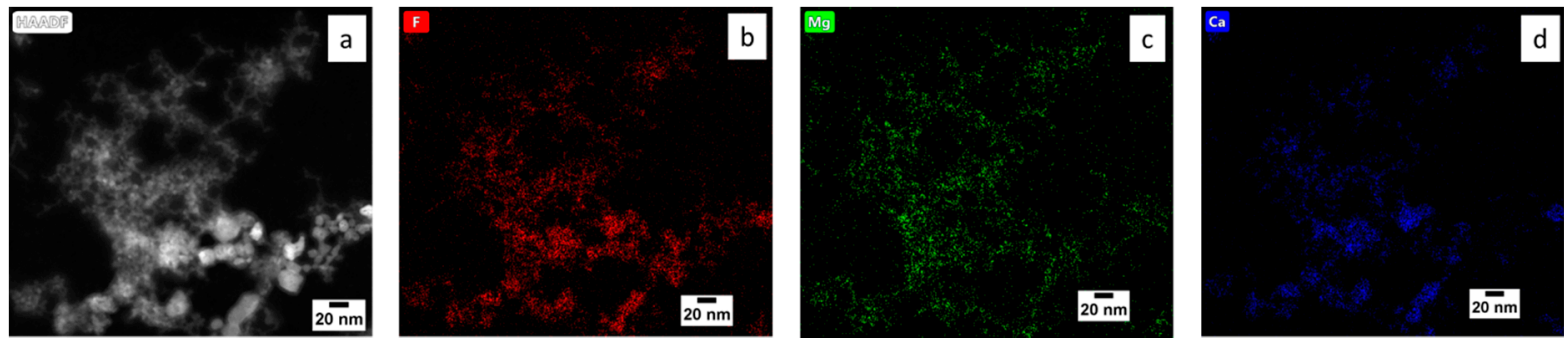

Figure 1. $\mathrm{MgF}_{2}$ and $\mathrm{CaF}_{2}$ nanoparticles synthesized in a sol: (a) HAADF-STEM image and the corresponding EDX maps; (b) Fluorine—red; (c) Magnesium—green; (d) Calcium—blue.

\subsection{Cytotoxicity of Nano Metal Fluorides}

All cell culture experiments were performed with two human in-vitro cell models, the liver cell line HepG2 and Caco-2, which can represent the human intestinal epithelium. These cell models were treated with the synthesized NMFs, stand-alone and combination. Cytotoxicity of all nanoparticles was low for both cell models in MTT assays as shown in Figure 2.
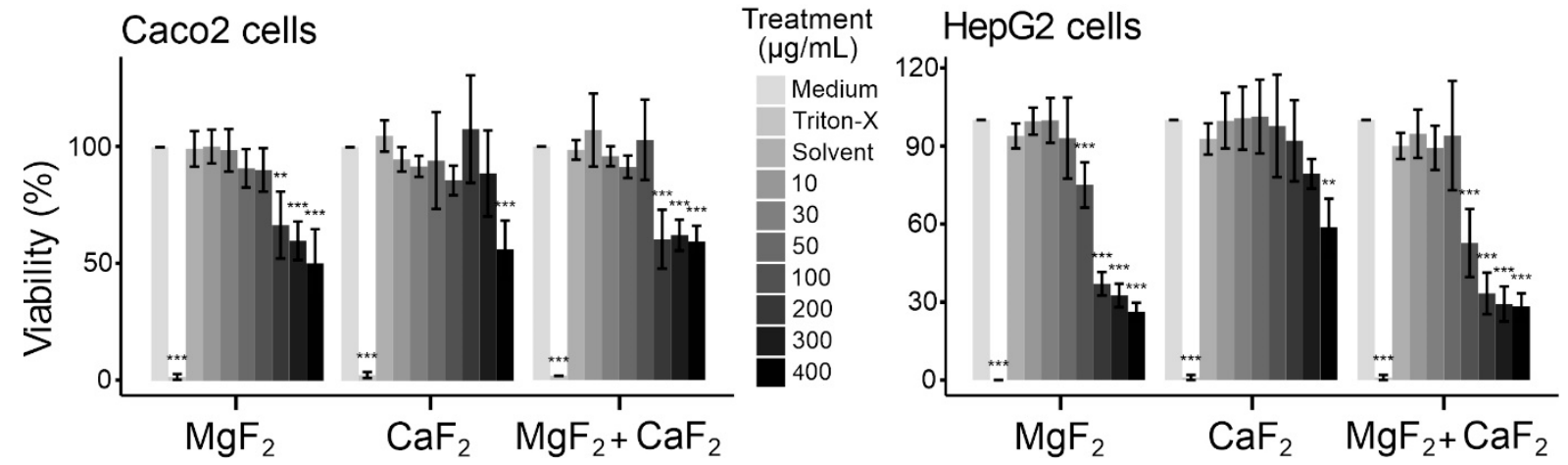

Figure 2. Cell viability of Caco-2 cells (left) and HepG2 cells (right) in MTT assays.

Cell viability was only impaired in concentrations of $200 \mu \mathrm{g} / \mathrm{mL}$ and $100 \mu \mathrm{g} / \mathrm{mL}$ and above for Caco-2 cells and HepG2 cells, respectively (Figure 2). It is observed that HepG2 cells are more sensitive to both nanoparticles. Nevertheless, both in-vitro cell models show low impact of the nanoparticles on cell viability and the concentrations causing cytotoxicity are considered high also in other toxicological studies with nanomaterials [28]. These results are similar to $\mathrm{MTT}$ assays done with $\mathrm{MgF}_{2}$ nanoparticles on human embryonic kidney cells which were reported to have no adverse effect on them [29].

\subsection{In-Vitro Agar Test}

The biocidal efficacy of nano metal fluorides was determined with an in-vitro agar test. The results of the test are presented in Figure 3. The $Y$ axis is the diameter of the fungal 
colony. The dotted horizontal line is the size of the original fungal inoculum. The control which did not contain NMFs had the maximum fungal colony diameter covering the whole Petri dish. Two concentration of NMFs in stand-alone and combination formulation were tested. At the lower concentration of $0.05 \mathrm{M}$, the fungal colony diameter of brown-rot fungus, $R$. placenta was the largest for $\mathrm{CaF} 2$-added agar medium and lowest in the medium containing the combination of $\mathrm{MgF} 2$ and $\mathrm{CaF} 2$. In contrast, the white-rot fungus T. versicolor was not inhibited by MgF2, CaF2, or their combination at the lower concentration of $0.05 \mathrm{M}$. At the higher NMF concentration of $0.4 \mathrm{M}$, there was complete inhibition of fungal growth, T. versicolor and R. placenta. Based on in-vitro agar results presented here, it was found that the combination of $\mathrm{MgF} 2$ and $\mathrm{CaF} 2$ would have more efficacy than the stand-alone NMF at the same concentration. Also, a higher concentration of NMF would increase the biocidal efficacy against brown-rot and white-rot fungi. Thus, the NMF formulations were optimized for the subsequent wood treatment and the EN 113 (1996) test.

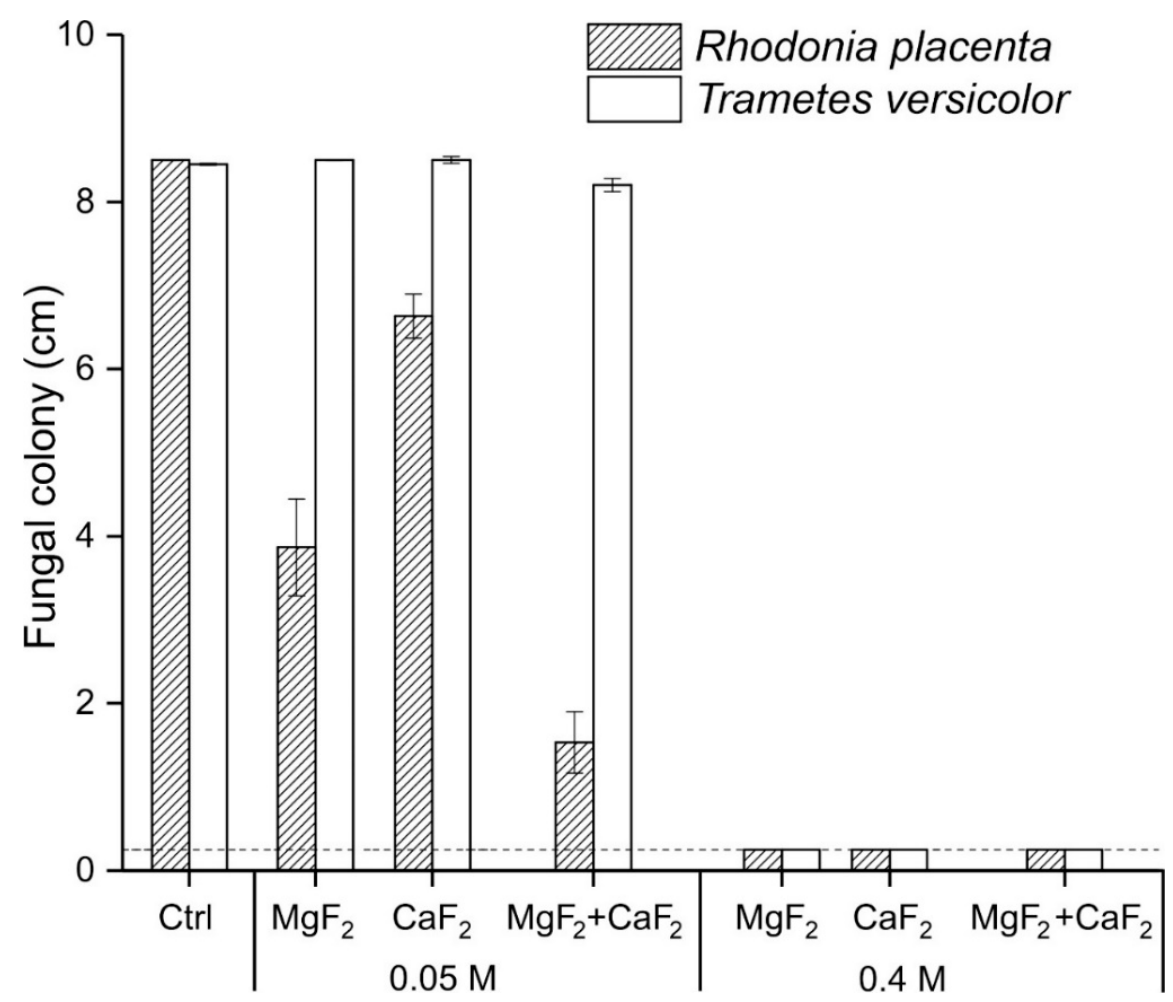

Figure 3. Biocidal efficacy of NMFs against R. placenta and T. versicolor.

\subsection{Characterization of Wood Treated with Nano Metal Fluorides}

The retention and WPG (\%) of NMF in treated wood is shown in Table 1 (with standard deviation in brackets). The increase in the concentration of $\mathrm{MgF}_{2}$ from $0.5 \mathrm{M}$ to $0.8 \mathrm{M}$ for wood treatment resulted in higher retention of $\mathrm{MgF}_{2}$. In wood treated with the combination of $\mathrm{MgF}_{2}$ and $\mathrm{CaF}_{2}$, the retention was similar to wood treated with $\mathrm{MgF}_{2}$ at $0.5 \mathrm{M}$. In addition, the WPG (\%) of wood treated with the combination of $\mathrm{MgF}_{2}$ and $\mathrm{CaF}_{2}$ was similar to specimens treated with only $\mathrm{MgF}_{2}$.

Table 1. Retention and WPG of NMF treated specimens.

\begin{tabular}{ccc}
\hline NMF Treatment & Retention $\mathbf{( k g / \mathbf { m } ^ { 3 } )}$ & WPG (\%) \\
\hline $\mathrm{MgF}_{2}(0.5 \mathrm{M})$ & $12.9(0.2)$ & $8.3(0.3)$ \\
\hline $\mathrm{MgF}_{2}(0.8 \mathrm{M})$ & $16.2(0.8)$ & $9.0(0.8)$ \\
\hline $\mathrm{MgF}_{2}+\mathrm{CaF}_{2}(0.5 \mathrm{M})$ & $13.3(0.3)$ & $10.6(0.8)$ \\
\hline
\end{tabular}


Wood treated with nano metal fluorides was characterized using X-ray micro-CT. The Figure 4 presents the reconstructed $X$-ray micro-CT image of the transverse section of NMF treated sapwood of Scots pine. The Figure 4a shows the unleached NMF treated wood and the Figure $4 \mathrm{~b}$ displays NMF treated wood that was leached. In the unleached NMF treated wood, aggregates of NMFs are observed as white spots in the lumina of the earlywood cells and the resin canals are empty. In contrast, NMF treated wood that was leached contain aggregates of NMFs in the resin canals. It is likely that leaching caused some of the nano metal fluorides to be redistributed from the earlywood cells into the resin canals. To further confirm the presence of NMFs in treated wood, it was characterized by MAS ${ }^{19} \mathrm{~F}$ NMR spectroscopy.
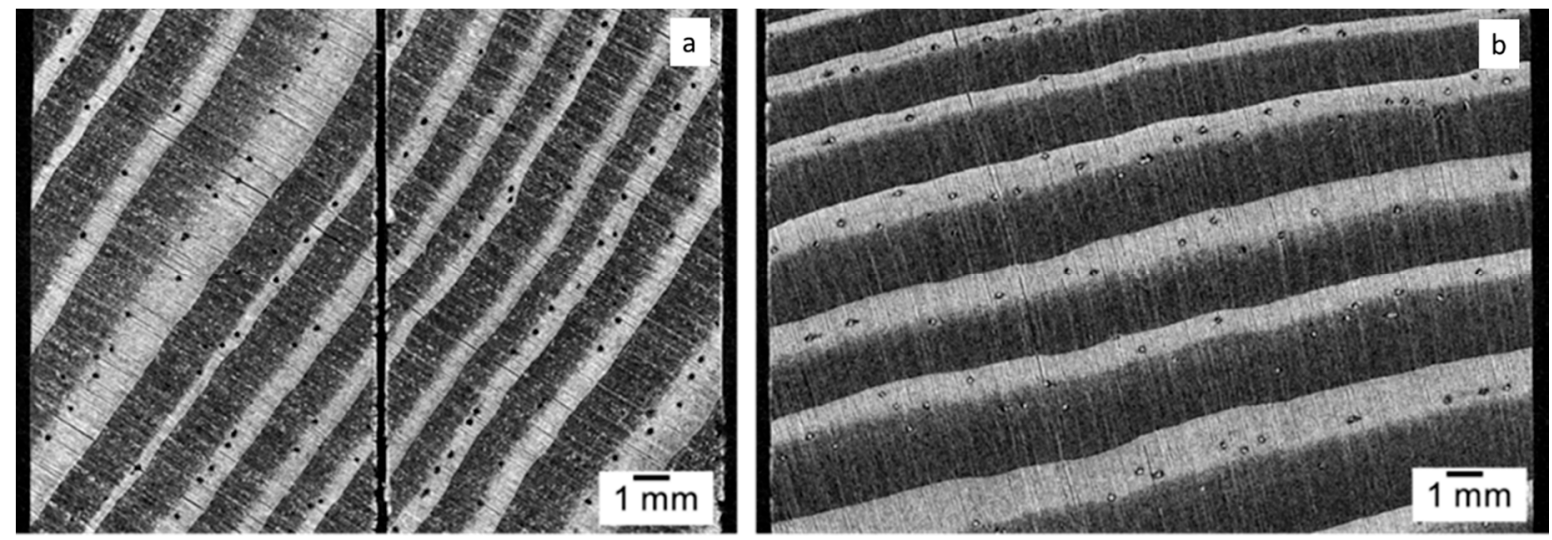

Figure 4. X-ray micro-CT images of the transverse section of Scots pine wood treated with NMFs: (a) before leaching; (b) after leaching.

The ${ }^{19}$ F MAS NMR spectra of Scots pine sapwood treated with combination of $\mathrm{MgF}_{2}$ and $\mathrm{CaF}_{2}$ (unleached and leached) are depicted in Figure 5. Both unleached and leached treated wood show signals that can be attributed to $\mathrm{MgF}_{2}$ with a chemical shift of $-198 \mathrm{ppm}$ and $\mathrm{CaF}_{2}$ with a chemical shift of $-108 \mathrm{ppm}$. The remaining signals in the spectra are spinning sidebands. The intensity of the signal attributed to $\mathrm{MgF}_{2}$ is lower in the leached treated wood than unleached treated wood. This is possibly due to the higher solubility of $\mathrm{MgF}_{2}(130 \mathrm{mg} / \mathrm{L})$ compared to $\mathrm{CaF}_{2}(16 \mathrm{mg} / \mathrm{L})$ [30]. Therefore, the accelerated ageing test causes more of $\mathrm{MgF}_{2}$ to be leached from treated wood than $\mathrm{CaF}_{2}$. Even though NMFs are leached from wood, it is important that a sufficient amount remains to be biocidal to fungi.

\subsection{Decay Resistance}

The average mass loss of virulence specimens against $R$. placenta were $18.4 \pm 2.3 \%$ and against T. versicolor was $19.4 \pm 3.4 \%$. The average mass losses of the treated specimens are shown in Figure 6. Specimens treated with only ethylene glycol had mass losses higher than $20 \%$, which is expected as the solvent did not protect against fungal decay. NaF treated specimens that were leached were also tested to compare with NMF treated specimens. Against $R$. placenta, NaF treated specimens had the highest mass loss which was greater than the virulence specimens. Also, wood treated with NMFs exhibited less decay than those treated with $\mathrm{NaF}$, evidenced even in visual assessment (Figure S1, Supplementary Section). Among the NMF treated specimens, the increase in concentration of $\mathrm{MgF}_{2}$ from $0.5 \mathrm{M}$ to $0.8 \mathrm{M}$ resulted in reducing the mass losses caused by both fungi to below $10 \%$. Although the average mass loss caused by T. versicolor in $\operatorname{MgF}_{2}(0.8 \mathrm{M})$ treated specimens was below 3\%, it was higher for specimens exposed to $R$. placenta. Only the specimens treated with the combination of $\mathrm{MgF}_{2}$ and $\mathrm{CaF}_{2}$ had mass losses below $3 \%$ against both fungi. Thus, they can be considered durable against $R$. placenta and T. versicolor. 


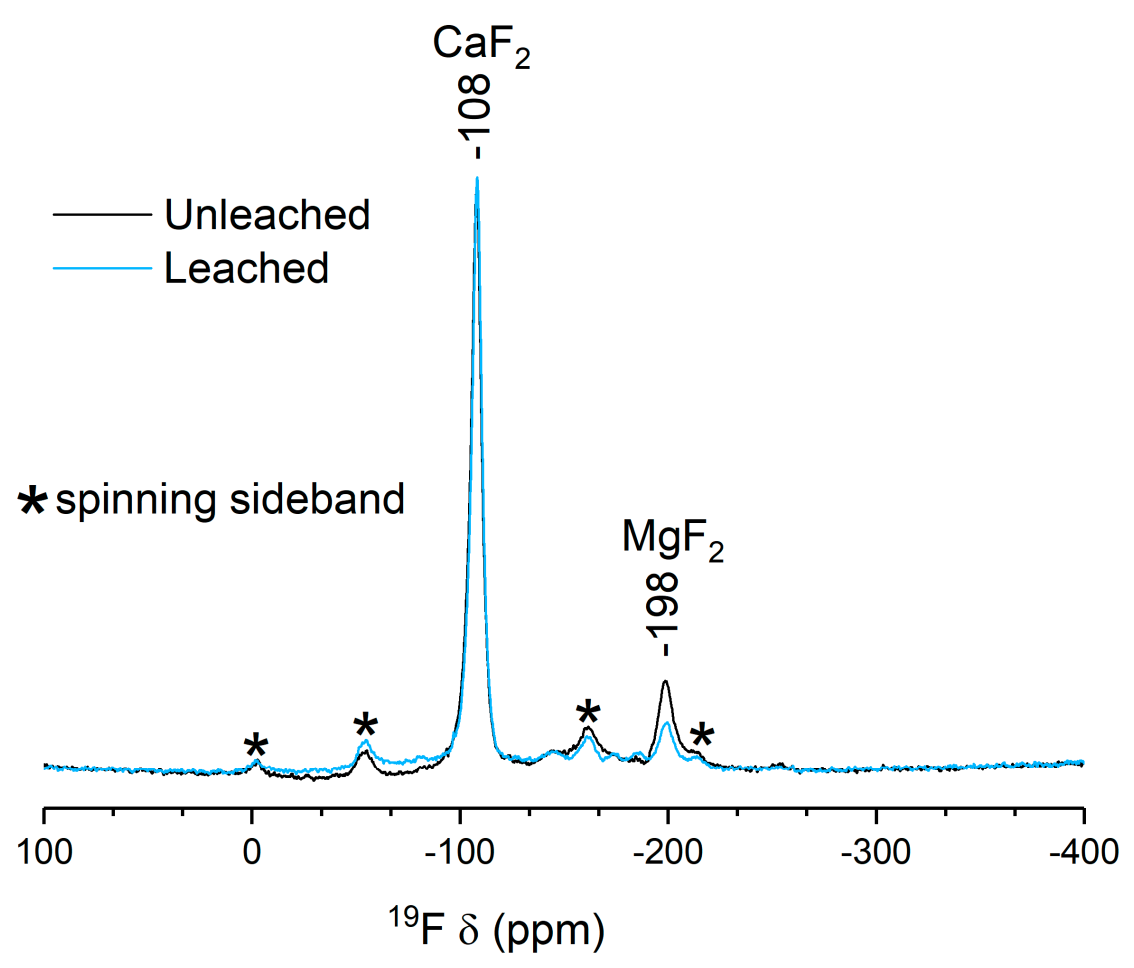

Figure 5. $\mathrm{MAS}{ }^{19} \mathrm{~F}$ (Larmor frequency: $376.4 \mathrm{MHz}$ ) NMR spectra of unleached treated $\left(\mathrm{MgF}_{2}+\mathrm{CaF}_{2}\right)$ (black) and leached treated $\left(\mathrm{MgF}_{2}+\mathrm{CaF}_{2}\right)$ wood (blue) specimens.

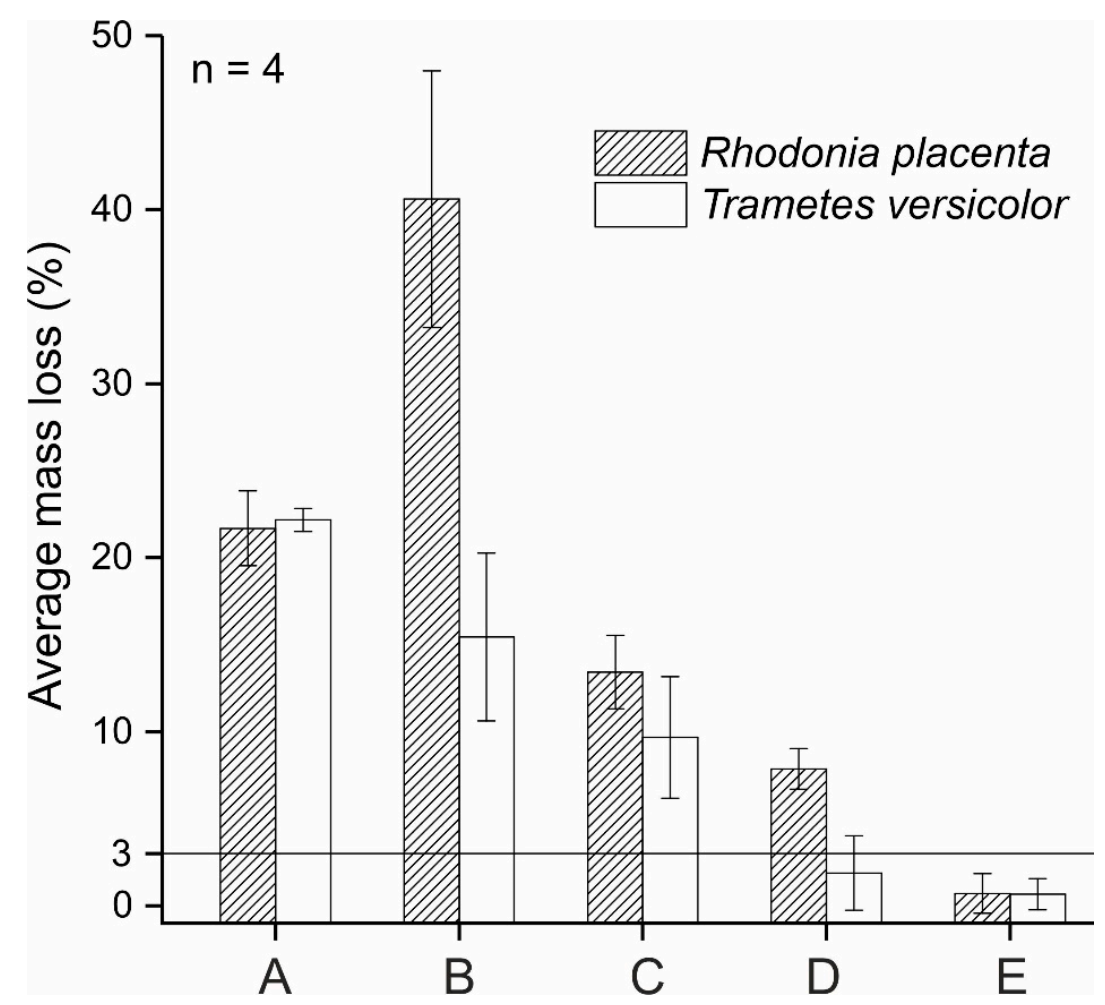

Figure 6. Average mass loss caused by R. placenta and T. versicolor. A-Ethylene glycol, B-NaF (1 M), $\mathrm{C}-\mathrm{MgF}_{2}(0.5 \mathrm{M}), \mathrm{D}-\mathrm{MgF}_{2}(0.8 \mathrm{M}), \mathrm{E}-\mathrm{MgF}_{2}+\mathrm{CaF}_{2}(0.5 \mathrm{M})$. The horizontal line is the mass loss cut-off at $3 \%$ for durability classification.

\section{Discussion}

The biocidal efficacy of combination of $\mathrm{MgF}_{2}$ and $\mathrm{CaF}_{2}$ against $R$. placenta and T. versicolor was demonstrated with an in-vitro agar test. In comparison $\mathrm{Cu}$-amine was reported to have 
limited protection against T. versicolor in an in-vitro agar test [25]. Thus, the combination of nano metal fluorides is more biocidal compared to $\mathrm{Cu}$-amine against $T$. versicolor.

Subsequently wood was treated with NMFs, leached, and characterized by MAS ${ }^{19} \mathrm{~F}$ NMR and X-ray micro-CT. It was observed that NMFs were present in treated wood even after leaching. This is likely due to their lower solubility. Although the retention values for NMF treated wood are higher than those reported for micronized copper [8], they were lower compared to nano zinc-borate treated wood which had retention of $17.9 \mathrm{~kg} / \mathrm{m}^{3}$ [31]. Decay resistance tests demonstrated that wood treated with NMF combination of $\mathrm{MgF}_{2}$ and $\mathrm{CaF}_{2}$ and leached had mass losses below 3\% against $R$. placenta and T. versicolor. This result is in agreement with results from in-vitro agar tests. Another significant finding of this study is that even after leaching, biocidal efficacy is provided by the combination of $\mathrm{MgF}_{2}$ and $\mathrm{CaF}_{2}$ against brown-rot and white-rot fungi.

The synergistic biocidal efficacy of the NMF combination could be due to several factors. First, the differences in their solubility with $\mathrm{MgF}_{2}$ having a higher solubility of $130 \mathrm{mg} / \mathrm{L}$ and $\mathrm{CaF}_{2}$ of $16 \mathrm{mg} / \mathrm{L}$ may have resulted in an optimal release of fluoride that was biocidal to both fungi [30]. Secondly, a metastable phase of $\mathrm{CaMgF}_{4}$ which has been reported before could have been formed that maintains sufficient fluoride aggregates within wood [32]. Thirdly, the NMF combination of low-water soluble fluorides in wood reduced the leaching of fluoride such that the amount remaining could still provide longterm protection against fungal decay. Further research needs to be done to determine the amount of fluoride present in wood at the end of the test and to investigate the tuning of the solubility of the metal fluorides in the combination that promotes its biocidal efficacy against fungi.

Still, NMF treated wood provides a better alternative than highly soluble $\mathrm{NaF}$ and $\mathrm{Na}_{2} \mathrm{SiF}_{6}$ formulations for wood preservation. Although decay resistance is reported for $\mathrm{TiO}_{2} /$ Ce against $R$. placenta and nano- $\mathrm{ZnO}$ against $T$. versicolor, there is no single nano-based wood treatment that had efficacy against both fungi after leaching $[16,17]$. An advantage of the use of nano metal fluorides in treated wood that was shown in this study is that they are safe to handle and can provide durability without the need for additional fixatives in outdoor applications with no soil contact. Future characterization studies need to be done to determine the inclusion of nano metal fluorides in cell walls. In addition, the durability of NMF treated wood can be tested against termites (white ant), blue-stain and soft-rot fungi.

\section{Conclusions}

Synthesis of low-water soluble metal fluorides in their nanoscopic form has opened the possibility of assessing their biocidal efficacy against wood-degrading fungi. NMFs have a low risk on human cell viability as observed from cytotoxicity assays that makes the resultant treated wood products safe for various applications in construction. The advantage of magnesium fluoride and calcium fluoride in comparison to conventional fluoride-based wood preservatives is their low water solubility. Results in the present study confirmed that NMFs were present in treated wood after accelerated ageing. More importantly, it is reported that wood treated with nano metal fluorides and leached had mass losses below $3 \%$ against brown-rot and white-rot fungi. Therefore, the NMF treatment of wood is considered to be durable according to EN 113 (1996) test. The results here demonstrate the viability of low-water soluble fluorides synthesized in their nanoscopic form to provide wood protection. In summary, their high biocidal efficacy, low susceptibility to leaching, and reduced risk to human health and environment demonstrates their potential to become the next generation of fluoride compounds for use in wood protection above ground.

Supplementary Materials: The following supporting information can be downloaded at: https: / www. mdpi.com/article/10.3390/app12031727/s1, Figure S1: Comparison of specimens after exposure to fungi, R. placenta. 


\begin{abstract}
Author Contributions: Conceptualization, S.M.U., E.K. and T.H.; methodology, S.M.U., L.V., E.K., I.S. and T.H.; software, S.M.U. and L.V.; validation, S.M.U. and L.V.; formal analysis, S.M.U.; investigation, S.M.U. (sol-synthesis, nanoparticle and treated wood characterization, in-vitro agar test, wood treatment, leaching, and fungal tests) and L.V. (cytotoxicity assays); resources, E.K., I.S. and T.H.; data curation, S.M.U.; writing—original draft preparation, S.M.U.; writing—review and editing, S.M.U., L.V., E.K. and I.S.; visualization, S.M.U.; supervision, E.K., I.S. and T.H.; funding acquisition, E.K. All authors have read and agreed to the published version of the manuscript.
\end{abstract}

Funding: This research received no external funding.

Institutional Review Board Statement: Not applicable.

Informed Consent Statement: Not applicable.

Acknowledgments: We thank Thoralf Krahl for support with the synthesis of $\mathrm{CaF}_{2}$ and $\mathrm{MgF}_{2}$ sol, Kerstin Klutzny for support with the in-vitro agar and wood decay testing, Dietmar Meinel for acquiring the X-ray micro-CT images, Christoph Erdmann for acquiring the HAADF-STEM images, and Gudrun Scholz for measuring the MAS ${ }^{19} \mathrm{~F}$ NMR spectra of NMF treated wood specimens. The results of this paper have been also published in the form of doctoral dissertation of S.M.U. at the Humboldt-Universität zu Berlin.

Conflicts of Interest: The authors declare no conflict of interest.

\title{
References
}

1. Churkina, G.; Organschi, A.; Reyer, C.P.O.; Ruff, A.; Vinke, K.; Liu, Z.; Reck, B.K.; Graedel, T.E.; Schellnhuber, H.J. Buildings as a global carbon sink. Nat. Sustain. 2020, 3, 269-276. [CrossRef]

2. Gustavsson, L.; Pingoud, K.; Sathre, R. Carbon dioxide balance of wood substitution: Comparing concrete- and wood-framed buildings. Mitig. Adapt. Strateg. Glob. Chang. 2006, 11, 667-691. [CrossRef]

3. Glover, J.; White, D.O.; Langrish, T.A.G. Wood versus concrete and steel in house construction: A life cycle assessment. J. For. 2002, 100, 34-41. [CrossRef]

4. Sandberg, D.; Kutnar, A.; Mantanis, G. Wood modification technologies-A review. iForest Biogeosci. For. 2017, 10, 895-908. [CrossRef]

5. Brischke, C. Timber. In Long-Term Performance and Durability of Masonry Structures; Elsevier: Amsterdam, The Netherlands, 2019; pp. 129-168; ISBN 9780081021118.

6. Jiang, J.; Zhou, Y.; Mei, C.; Cao, J. Polyethylene glycol and silica sol penetration improves hydrophobicity and dimensional stability of wood after a short-time treatment. Eur. J. Wood Wood Prod. 2021, 79, 1395-1404. [CrossRef]

7. Shabir Mahr, M.; Hübert, T.; Stephan, I.; Militz, H. Decay protection of wood against brown-rot fungi by titanium alkoxide impregnations. Int. Biodeterior. Biodegrad. 2013, 77, 56-62. [CrossRef]

8. Freeman, M.H.; McIntyre, C.R. A Comprehensive Review of Copper-Based Wood Preservatives with a focus on new micronized or dispersed copper systems. For. Prod. J. 2008, 58, 6-27.

9. Freeman, M.H.; McIntyre, C.R.; Jackson, D. A Critical and Comprehensive Review of Boron in Wood Preservation. Proc. Am. Wood Prot. Assoc. 2009, 105, 279-294.

10. Gomes, S.I.L.; Murphy, M.; Nielsen, M.T.; Kristiansen, S.M.; Amorim, M.J.B.; Scott-Fordsmand, J.J. Cu-nanoparticles ecotoxicityExplored and explained? Chemosphere 2015, 139, 240-245. [CrossRef]

11. Papadopoulos, A.N.; Bikiaris, D.N.; Mitropoulos, A.C. Nanomaterials and Chemical Modifications for Enhanced Key Wood Properties: A Review. Nanomaterials 2019, 9, 607. [CrossRef]

12. Taghiyari, H.R.; Moradi-Malek, B.; Ghorbani Kookandeh, M.; Farajpour Bibalan, O. Effects of silver and copper nanoparticles in particleboard to control Trametes versicolor fungus. Int. Biodeterior. Biodegrad. 2014, 94, 69-72. [CrossRef]

13. Nair, S.; Pandey, K.K.; Giridhar, B.N.; Vijayalakshmi, G. Decay resistance of rubberwood (Hevea brasiliensis) impregnated with $\mathrm{ZnO}$ and $\mathrm{CuO}$ nanoparticles dispersed in propylene glycol. Int. Biodeterior. Biodegrad. 2017, 122, 100-106. [CrossRef]

14. Bak, M.; Németh, R. Effect of Different Nanoparticle Treatments on the Decay Resistance of Wood. BioResources 2018, 13, 7886-7899. [CrossRef]

15. Harandi, D.; Ahmadi, H.; Mohammadi Achachluei, M. Comparison of $\mathrm{TiO} 2$ and $\mathrm{ZnO}$ nanoparticles for the improvement of consolidated wood with polyvinyl butyral against white rot. Int. Biodeterior. Biodegrad. 2016, 108, 142-148. [CrossRef]

16. Lykidis, C.; Bak, M.; Mantanis, G.; Németh, R. Biological resistance of pine wood treated with nano-sized zinc oxide and zinc borate against brown-rot fungi. Eur. J. Wood Wood Prod. 2016, 74, 909-911. [CrossRef]

17. Guo, H.; Bachtiar, E.V.; Ribera, J.; Heeb, M.; Schwarze, F.W.M.R.; Burgert, I. Non-biocidal preservation of wood against brown-rot fungi with a TiO2/Ce xerogel. Green Chem. 2018, 20, 1375-1382. [CrossRef]

18. Becker, G. Fluorine compounds for wood preservation. J. Inst. Wood Sci. 1973, 6, 51-62.

19. Pan, C.; Ruan, G.; Chen, H.; Zhang, D. Toxicity of sodium fluoride to subterranean termites and leachability as a wood preservative. Eur. J. Wood Wood Prod. 2014, 73, 97-102. [CrossRef] 
20. Tascioglu, C.; Umemura, K.; Kusuma, S.S.; Yoshimura, T. Potential utilization of sodium fluoride (NaF) as a biocide in particleboard production. J. Wood Sci. 2017, 63, 652-657. [CrossRef]

21. Humar, M.; Peek, R.D.; Jermer, J. Regulations in the European Union with Emphasis on Germany, Sweden and Slovenia. Environ. Impacts Treat. Wood 2006, 6495, 37-57. [CrossRef]

22. Roark, R.C. Fluorides vs. Fluosilicates as Insecticides. Science 1926, 63, 431-432. [CrossRef]

23. Usmani, S.M.; Stephan, I.; Hübert, T.; Kemnitz, E. Nano Metal Fluorides for Wood Protection against Fungi. ACS Appl. Nano Mater. 2018, 1, 1444-1449. [CrossRef]

24. Usmani, S.M.; Plarre, R.; Hübert, T.; Kemnitz, E. Termite resistance of pine wood treated with nano metal fluorides. Eur. J. Wood Wood Prod. 2020, 78, 493-499. [CrossRef]

25. Pantano, D.; Neubauer, N.; Navratilova, J.; Scifo, L.; Civardi, C.; Stone, V.; Von Der Kammer, F.; Müller, P.; Sobrido, M.S.; Angeletti, B.; et al. Transformations of Nanoenabled Copper Formulations Govern Release, Antifungal Effectiveness, and Sustainability throughout the Wood Protection Lifecycle. Environ. Sci. Technol. 2018, 52, 1128-1138. [CrossRef] [PubMed]

26. DIN EN 113. Wood Preservatives Test Method for Determining the Protective Effectiveness against Wood Destroying Basidiomycetes. In Determination of Toxic Values; European Committee for Standardization: Brussels, Belgium, 1996.

27. DIN EN 84. Wood Preservatives Accelerated Ageing of Treated Wood Prior to Biological Testing Leaching Procedure; European Committee for Standardization: Brussels, Belgium, 1997.

28. Voss, L.; Hoché, E.; Stock, V.; Böhmert, L.; Braeuning, A.; Thünemann, A.F.; Sieg, H. Intestinal and hepatic effects of iron oxide nanoparticles. Arch. Toxicol. 2021, 95, 895-905. [CrossRef] [PubMed]

29. Lellouche, J.; Friedman, A.; Lahmi, R.; Gedanken, A.; Banin, E. Antibiofilm surface functionalization of catheters by magnesium fluoride nanoparticles. Int. J. Nanomed. 2012, 7, 1175-1188. [CrossRef]

30. Lide, D.R. CRC Handbook of Chemistry and Physics: A Ready-Reference Book of Chemical and Physical Data; CRC Press: Boca Raton, FL, USA, 2003; pp. 4-37.

31. Lykidis, C.; Mantanis, G.; Adamopoulos, S.; Kalafata, K.; Arabatzis, I. Effects of nano-sized zinc oxide and zinc borate impregnation on brown rot resistance of black pine (Pinus nigra L.) wood. Wood Mater. Sci. Eng. 2013, 8, 242-244. [CrossRef]

32. Krahl, T.; Broßke, D.; Scheurell, K.; Lintner, B.; Kemnitz, E. Novel aspects in the chemistry of the non-aqueous fluorolytic sol-gel synthesis of nanoscaled homodisperse MgF2 sols for antireflective coatings. J. Mater. Chem. C 2016, 4, 1454-1466. [CrossRef] 